\title{
Transfer in $\mathrm{L}_{3}$ acquisition
}

\section{How does L2 aspectual knowledge in English influence the acquisition of perfective and imperfective aspect in $\mathrm{L}_{3}$ Spanish among German-speaking learners?}

\author{
Lukas Eibensteiner \\ University of Mannheim
}

The present study examines the influence of L2 English on the acquisition of perfective and imperfective aspect in L3 Spanish among Germanspeaking learners. We will argue that English will be activated as the default transfer source due to principles of acquisition, which are similar for both the $\mathrm{L}_{2}$ and the $\mathrm{L}_{3}$, and because of structural similarities between both languages. The analysis is based on data from 36 German-speaking learners with varying levels of knowledge of aspect in English, their L2, and learning Spanish. For data elicitation, two semantic interpretation tasks were used. The findings show that aspectual knowledge in L2 English affects the acquisition of $\mathrm{L}_{3}$ Spanish past tenses. However, the positive effect is not comprehensive, but rather, restricted to certain semantic contexts (e.g., past/ perfective contexts). The discussion points to the possible effects of oversimplified one-to-one-mappings of form and meaning between L2 English and $\mathrm{L}_{3}$ Spanish.

Keywords: tense and aspect, German, English and Spanish language, third language acquisition, transfer, cross-linguistic influence

\section{Overview}

Linguistic transfer has traditionally been described as "the influence resulting from the similarities and differences between the target language and any other language that has been previously (and perhaps imperfectly) acquired" (Odlin, 1989, p. 27). Different studies have shown that several factors influence transfer (e.g., typological similarities, psychotypology, L2-status, proficiency) (e.g., De 
Angelis, 2007). In particular, it has been argued that structural similarities between two languages (i.e., typological closeness) are highly influential in the occurrence of transfer (e.g., Rothman, 2015). In addition to actual linguistic similarities, Kellerman (1983,p.114) introduces the concept of psychotypology, which refers to the "learner's [subjective] perception of language distance".

In our understanding, the notion of psychotypology is mainly based on explicit learning mechanisms and declarative memory. Following the declarative/ procedural model of language acquisition (Ullman, 2001), one has to distinguish between linguistic information stored in procedural memory that is accessed implicitly (e.g., skills and habits, but also underlying grammatical information) and linguistic information stored in declarative memory that is accessed explicitly (e.g., knowledge of rules). The model claims that the mechanisms underlying $\mathrm{L}_{1}$ and $\mathrm{L}_{2} / \mathrm{L}_{3}$ acquisition are essentially different from each other. For example, it predicts that the "processing of linguistic forms that are computed grammatically by procedural memory in $\mathrm{L} 1$ is expected to be dependent to a greater extent upon declarative memory in L2" (Ullman, 2001,p.109) or L3 acquisition. Additionally, learners seem to possess a conscious desire to suppress the L1 as being non-foreign and therefore prefer to rely on a prior L2 as a learning strategy for the $\mathrm{L}_{3}$ (De Angelis \& Selinker, 2001). Both assumptions explain the privileged role for transfer of the $\mathrm{L}_{2}$ system that has been observed in the $\mathrm{L}_{3}$ literature (e.g., Bardel \& Falk, 2012). This does not mean that L1 transfer is impossible, however. As $\mathrm{L}_{3}$ learning relies mainly on declarative memory sources and learners seem to possess a desire to suppress their L1, L1 transfer is rather unlikely, unless the learners have explicit L1 knowledge and change their learning strategy (Falk, Lindqvist, \& Bardel, 2015). However, several authors have argued against such a privileged role of the $\mathrm{L}_{2}$ in cases where the $\mathrm{L}_{1}$ is typologically closer to the $\mathrm{L}_{3}$ (e.g., Rothman, 2015).

Based on these theoretical assumptions, we argue that a morphological similarity between the target language (TL) and the L1/L2 guides learners' attention and helps them to perceive the TL and the $\mathrm{L}_{1} / \mathrm{L}_{2}$ as formally similar. Normally, such a perception of formal similarity goes hand in hand with the "assumption of an associated semantic and/or functional similarity" (Ringbom, 2007, p.25; emphasis in original). The learner assumes that the TL functions like the L1/ L2 and maps the functions or meanings of the existing $\mathrm{L}_{1} / \mathrm{L}_{2}$ directly onto the TL items. According to Ringbom (2007, p.5), such cross-linguistic relationships can be termed 'similarity relations'. He additionally claims that trying to establish such one-to-one relationships between the TL and a unit in another language is a natural tendency in learners, which "is frequently in conflict with the actual network of one-to-many or many-to-many relations in the real world" (Ringbom, 2007, p.56). Those relationships, in which "the learner perceives a TL item or 
pattern as in important ways differing from an L1 [or L2] form or pattern, though there is also an underlying similarity between them", can be termed 'contrast relations' (Ringbom, 2007, p. 6).

In general, when formal and functional similarities can be established, and actual and perceived similarities coincide, a positive transfer occurs; if not, a negative transfer occurs. We argue that, in similarity relations, learners perceive the similarities between the TL and the $\mathrm{L}_{1} / \mathrm{L}_{2}$ as a useful learning strategy and are able to map the $\mathrm{L}_{1} / \mathrm{L}_{2}$ items or patterns directly onto the TL, which results in positive transfer. However, contrast relations are more difficult to gather, which makes positive transfer more unlikely.

\section{Tense and aspect in German, English and Spanish}

Tense is the grammaticalized expression of time, whereas aspect is usually described as "different ways of viewing the internal temporal constituency of a situation" (Comrie, 1976, p.3). Perfective aspect refers to the totality of the situation, whereas imperfective aspect makes "explicit reference to the internal temporal structure of a situation, viewing a situation from within" (Comrie, 1976, p. 24). The latter is usually divided into habitual, continuous and progressive aspect. A language possesses habitual aspect if it has a grammaticalized form used to describe "a regular iteration of an event, such that the resulting habit is regarded as a characteristic property of a given referent" (Bertinetto \& Lenci, 2012, p. 852). Progressive aspect focalizes "the notion of an event viewed as going on at a single point in time" (Bertinetto, Ebert, \& De Groot, 2000, p. 527). In general, progressive aspect is not combinable with stative predicates, whereas continuous aspect is. Furthermore, for continuous aspect the reference point is not a single point in time, but a time span, thereby stressing the durative character of the event (Mair, 2012).

German is a so-called non-aspect language (e.g., Andersson, 2004). Both German past tenses (Perfekt and Präteritum) can convey the same temporal notion of pastness. To express aspectual distinctions, lexical or pragmatical devices are used. For example, progressive meaning can be expressed by the particle gerade, the periphrasis dabei sein $z u$, or the so-called Rheinische Verlaufsform (sein + am + substantivized infinitive) (see Example (1)). It should be mentioned that the Rheinische Verlaufsform is not systematically used in standard German and is restricted to some spoken dialects in the south of Germany.

(1) Max schrieb gerade/war dabei zu schreiben/war am Schreiben, als ich den Raum betrat.

'Max was writing when I entered the room.' 
German does not possess any grammatical device to express the notion of habituality either. Instead, German speakers have to rely on, for example, temporal adverbials conveying repetition.

English, in contrast, possesses an obligatory and fully grammaticalized progressive aspect (be $+\mathrm{V}$-ing), which has to be used in all tenses (e.g., Declerck, 2006). In the past domain, the aspectual opposition is expressed with the nonprogressive Simple Past and the progressive periphrasis. The notion of habituality is conveyed by the periphrasis used to + infinitive or would + infinitive (e.g., Declerck, 2006) or the Simple Past in combination with a repetitive adverb (Tagliamonte \& Lawrence, 200o).

In Spanish, the aspectual distinction between perfective (perfecto simple, Preterite) and imperfective (imperfecto, Imperfect) meaning can only be found in the past domain (e.g., Zagona, 2012; see Example (2)).

(2) Ayer habló con Juan. Mientras hablaba se le cayó el móvil.

'Yesterday he talked with Juan. While he was talking, his mobile phone fell down.'

In Example (2), the use of habló denotes a perfective viewpoint, whereas hablaba emphasises the action of talking without expressing the boundaries of the situation. The Spanish Imperfect can also convey continuous and habitual meaning (Examples (3) and (4)).

(3) Martina llevaba una falda roja en la fiesta del sábado.

'Martina was wearing a red skirt at the party on Saturday.'

(4) De pequeño jugaba al fútbol.

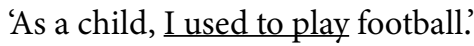

Like English, Spanish possesses a periphrastic construction (estar + gerundio), which can be used to express progressive meaning (e.g., Yllera, 1999; see Example (5)).

(5) Juan estaba/estuvo hablando con María.

'Juan was talking with Maria.'

\section{Transfer in the acquisition of tense and aspect in Spanish as $\mathrm{L}_{2} / \mathrm{L}_{3}$}

One of the well-known hypotheses concerning the L2 acquisition of tense and aspect, the Default Past Tense Hypothesis (Salaberry, 2008), claims that learners use a single marker of past tense across lexical aspectual classes, which can be explained by reliance on the tempo-aspectual system of their L1. In the initial 
developmental stages, the learners "transfer whatever inflectional or periphrastic markers of aspectual meaning they have" (Salaberry, 2008, p. 213). In fact, several studies have shown that tempo-aspectual representations of the L1 influence the acquisition of aspectual distinctions in an L2 (e.g., Diaubalick \& GuijarroFuentes, 2019). However, there is still little research on the influence of an L2 on the acquisition of an $\mathrm{L}_{3}$ in the realms of tense and aspect in $\mathrm{L}_{3}$ Spanish (Salaberry, in preparation) and the question arises to what extent the tempo-aspectual system of an L2 influences the acquisition of (im-)perfective aspect in $\mathrm{L}_{3}$ Spanish.

Foote (2009) investigated whether imperfective meaning from one Romance language can be transferred to another. She provided a sentence conjunction judgment task, in which the use of the perfective form renders the sentence illogical. Overall, her results show that participants who were able to recur to a Romance language had significantly better results in the test than the Anglophone learners in the L2 group. She interprets her results as showing a positive transfer of the "semantic contrasts between Romance past tenses from the previously known Romance language, whether L1 or L2" (Foote, 2009, p. 109).

Salaberry (2005) investigates the influence of L2 Spanish on the acquisition of L3 Portuguese by L1 English speakers. In general, his results show that the learners had achieved a high level of proficiency in the selection of past tense aspectual marking in the $\mathrm{L}_{3}$. Nevertheless, there was a discrepancy with stative predicates, where $\mathrm{L}_{3}$ learners were less consistent in their choices than native speakers of Portuguese. "Hence, it appears that the influence of the L1 English conceptualization of aspectual knowledge [...] had an effect on the conceptualization of non-prototypical markers of states" (Salaberry, in preparation). He argues that only invariant meanings (i.e., prototypical contexts, for example, the combination of imperfective aspect with states or perfective aspect with telics) can be acquired, because these notions can be learned with the help of explicit learning processes. Hence, complex meanings (i.e., non-prototypical contexts, for example, the combination of perfective aspect with states or imperfective aspect with telics) cannot, because learners have to rely on specific implicit learning mechanisms that are only available in L1 acquisition. If we follow the lines of argumentation, this leads to the claim that only invariant meanings expressed by prototypical contexts can be transferred from an $\mathrm{L}_{2}$ to an $\mathrm{L}_{3}$, simply because these are the only notions that can be acquired by an L2 learner. With regard to complex meanings expressed by non-prototypical contexts the $\mathrm{L}_{3}$ learners have to rely on their L1 (Salaberry, in preparation).

The assumptions presented above were the starting point for a study (Diaubalick, Eibensteiner, \& Salaberry, in preparation) in which the influence of prototypicality on the possibility of transfer of (im-)perfective meaning from one Romance language to another was investigated. The researchers conducted a 
written 40-item discourse-based forced-choice task (Salaberry, 2011) with a native control group $(n=149)$ and 73 Germanophone multilinguals learning Spanish as $\mathrm{L}_{3} / \mathrm{L}_{4} / \mathrm{Ln}$. The experimental group was divided into three groups according to proficiency in other Romance languages (i.e., no, basic (A1-B1 CEFR) or advanced knowledge (B2-C2 CEFR) in at least one Romance language). Preliminary results show that in prototypical contexts the choices of learners who have advanced knowledge of a Romance L2 overlap most often with those of native speakers, whereas learners with basic or without knowledge of a Romance L2 contrast significantly with native speakers. For the non-prototypical contexts, in contrast, all participants behave rather alike regarding stative predicates in the foreground. As for telic predicates in the background, all learners contrast significantly with native speakers, but not with each other. As the results show a positive influence of a Romance L2 only in prototypical, but not in non-prototypical contexts, the authors interpret their results as confirmatory for Salaberry's claim that L2 transfer can only occur in prototypical contexts, because these are the contexts that non-native learners are able to acquire in a second language.

\section{The present study}

In the present study, we focus on the influence of L2 English on the acquisition of past tenses in L3 Spanish. On a theoretical basis, one can argue that L2 English will be activated as the default transfer source for the following reasons: (1) Both $\mathrm{L}_{2}$ and $\mathrm{L}_{3}$ acquisition are mainly based on declarative learning mechanisms. (2) Learners possess a conscious desire to suppress the L1 system and use the L2 as a learning strategy for the $\mathrm{L}_{3}$ (see Chapter 1 for both assumptions). (3) Furthermore, due to the high amount of Latin lexis (Leisi \& Mair, 2008), for example, English can be described as being typologically closer to Spanish than German. (4) As German does not possess any grammaticalized aspectual distinction, it is rather unlikely that learners will explicitly rely on linguistic knowledge of that language. Consequently, structural similarities between English and Spanish should guide learners' attention. As a result, in similarity relations, they should be able to realize morphological as well as functional/semantic similarities (e.g., Simple Past and perfecto simple or be + verb-ing and estar + gerundio), which should result in positive transfer. However, in those contexts where learners do not perceive a similarity between English and Spanish (i.e., contrast relations), positive L2 transfer is rather unlikely. Finally, in contexts in which a form-meaning remapping between English and Spanish is required (e.g., contexts in which in English the Simple Past is used, but in Spanish the Imperfect is required, such as habitual or continuous 
contexts), positive transfer is quite improbable as well. However, learners may still rely on the English system, which would result in negative transfer.

\subsection{Predictions}

Based on the theoretical framework presented above, we hypothesize that learners' knowledge of aspect in English has a positive effect on the acquisition of Spanish (im-)perfective aspect. We predict that

1. German-speaking learners of $\mathrm{L}_{3}$ Spanish who have an advanced knowledge of aspectual differences in L2 English (group B) will outperform those learners who have only a basic aspectual knowledge in English (group A).

Furthermore, we hypothesize that the influence of aspectual knowledge in English will only be positive in similarity relations. In contrast relations or in contexts in which the form-meaning mappings between English and Spanish are quite different, we will find no positive influence. In short, we predict that group B will outperform group $\mathrm{A}$ in

2. perfective contexts and

3. progressive contexts in which estar + gerundio is contrasted with the Preterite.

However, we also predict that there will be no difference between group $B$ and group A in

4. progressive (contrasting Imperfect and Preterite),

5. habitual and

6. continuous contexts.

Furthermore, as Salaberry (in preparation; see Chapter 3) points out, such a positive transfer from an $\mathrm{L}_{2}$ to an $\mathrm{L}_{3}$ should only be possible in prototypical, but not in non-prototypical contexts. Consequently, we predict that

7. there will be no difference between group B and group A in non-prototypical combinations of grammatical and lexical aspect.

\subsection{Instruments and data coding}

For the present study, the following instruments were used: (1) a c-test for an overall proficiency measure in Spanish, (2) a background questionnaire and (3) two semantic interpretation tasks (SIT), in which the participants had to rate the correctness of two sentences on a Likert-scale from -2 ("I am very sure that this is wrong") to +2 ("I am very sure that this is correct"). The interpretation tasks were 
used for the following reasons: First, such a task enables learners' judgements to be tested in specific contexts relevant for the research question. Second, in contrast to simple grammaticality judgement tests, it provides a short context that is important for choosing the appropriate aspectual meaning. Following the procedure of the SPLLOC research team (e.g., Domínguez, Tracy-Ventura, Arche, Mitchell, \& Myles, 2013, p. 570), the contexts were given in German to make sure that the beginning learners were also able to understand them properly.

For English, the difference between the Simple Past and the Past Progressive was tested. The task contained five past (Example (6)) and seven progressive contexts (Example (7)) (six activity and six telic predicates plus three distractor items).

(6) Paul is a construction worker. Last month, with the help of his colleagues, he finally built the bridge. ${ }^{1}$

$\rightarrow$ Paul and his colleagues built the bridge.

$\rightarrow$ Paul and his colleagues were building the bridge.

(7) Lena was writing an e-mail to Bernhard. However, she was not able to finish writing, because her mother entered the room and interrupted her.

$\rightarrow$ She wrote an e-mail.

$\rightarrow$ She was writing an e-mail.

The Spanish interpretation task contained ten perfective (Example (8)), twelve progressive (contrasting Imperfect/estar + gerundio and Preterite; Example $(9) /(10)$ ), four continuous (Example (11)) and four habitual contexts (Example (12)) (eleven telic, eleven activity and eight stative predicates plus five distractor items). ${ }^{2}$

(8) My sister and I went to the 'Bodensee' to swim. We spent the whole weekend there and we enjoyed the cold water.

$\rightarrow$ Mi hermana y yo nadamos en el lago.

$\rightarrow$ Mi hermana y yo nadábamos en el lago.

'My sister and I swam/were swimming in the lake.'

1. In the original task, all the contexts were given in German and not in English, so that the tense equivalences between the context and the sentences (e.g., was writing an e-mail in Example (7)) did not occur. For the purpose of the present article and for a better comprehension, we translated all the German contexts into English. The correct answers are underlined.

2. Some of the items are based on Montrul and Slabakova (2002) and on the task constructed by the SPLLOC research team and are used with the permission of Laura Domínguez. 
(9) On Sunday Mario helped me building a tree house. Shortly before we were done, a storm arose, which made it impossible for us to finish the construction.

$\rightarrow$ Construimos una casa en el árbol, pero la tormenta nos interrumpió.

$\rightarrow$ Construíamos una casa en el árbol, pero la tormenta nos interrumpió.

'We built/were building a tree house, but the storm interrupted us.'

(10) I was swimming ten laps in the swimming pool. After five laps I had no strength and I had to take a break.

$\rightarrow$ Nadé diez largos.

$\rightarrow$ Estaba nadando diez largos.

'I swam/was swimming ten laps.'

(11) The film was supposed to start at seven o'clock. But as always, it started after half an hour of advertisements.

$\rightarrow$ La película fue a las siete pero empezó a las siete y media.

$\rightarrow$ La película era a las siete pero empezó a las siete y media.

'The film was at seven but it started at half past seven.'

(12) When Harry was a teenager, he used to go to the park with his friends to have a picnic.

$\rightarrow$ Harry comió con sus amigos en el parque.

$\rightarrow$ Harry comía con sus amigos en el parque.

'Harry ate/used to eat with his friends in the park.'

For Spanish, we calculated the means of the grammatical and ungrammatical sentences ${ }^{3}$ and added them up in order to obtain ratings between -4 and +4 .

\subsection{Participants}

All participants $(N=36)$ were instructed learners of Spanish attending English and Spanish classes in southern German or Austrian high schools. We divided the participants into two groups according to their accuracy scores in the English interpretation task. Participants who scored below $80 \%$ were put into group A and were regarded as having basic knowledge of aspectual differences in English. Those with accuracy ratings over $80 \%$ were regarded as having advanced knowledge and were put into group B. In general, participants were 16 to 19 years old (15 male and 21 female). Both groups were comparable with regard to their grade point average (grades in Biology, German, English, History and Math were collected) and no significant differences were found. The same is true for their overall Spanish proficiency (see c-test results in Table 1). Finally, as Table 1 shows,

3. To obtain only positive values, we changed the minus signs of the ungrammatical items. 
both groups differed significantly with regard to their aspectual knowledge in English.

Table 1. Participants

\begin{tabular}{llcccc}
\hline & $\begin{array}{l}\text { Aspectual knowledge } \\
\text { English }\end{array}$ & N & Mean & $\begin{array}{c}\text { Standard } \\
\text { deviation }\end{array}$ & p-value \\
\hline Age & basic & 18 & 17.50 & 0.857 & $=1.0$ \\
& advanced & 18 & 17.50 & 0.985 & \\
Grade point average & basic & 18 & 2.77 & 0.72 & $=0.122$ \\
& advanced & 18 & 2.38 & 0.75 & \\
C-Test (Spanish) & basic & 18 & 70.22 & 12.62 & $=0.377$ \\
& advanced & 18 & 74.72 & 17.18 & \\
Aspectual knowledge in & basic & 18 & $64.28 \%$ & 9.17 & $<0.001$ \\
English & advanced & 18 & $86.35 \%$ & 7.23 & \\
\hline
\end{tabular}

\section{Results}

Regarding prediction 1, we found a general trend that those who obtained better results in the English SIT also obtained better results in the Spanish one. This is shown by group means of 0.91 for group A and of 1.43 for group B. However, a $t$-test showed that the difference between both groups was not significant $(t(34)=-1.667, p=.105)$. Consequently, on a statistical basis, prediction 1 cannot be confirmed.

In a second analysis, we looked at whether transfer depends on specific semantic contexts (prediction $2\left(\mathrm{P}_{2}\right), 3\left(\mathrm{P}_{3}\right), 4\left(\mathrm{P}_{4}\right), 5\left(\mathrm{P}_{5}\right)$ and $6(\mathrm{P} 6)$; for a summary of the results, see Figure 1). In prediction 2, we claim that learners of group $\mathrm{B}$ will outperform learners of group A in perfective contexts. This was actually the case. As $t$-test results show, the mean of group A $(\bar{x}=0.69)$ differed significantly to that of group B $(\bar{x}=1.67)(t(34)=-2.479, p=.018)$. For progressive contexts with estar + gerundio $\left(\mathrm{P}_{3}\right)$ we also hypothesized a positive influence of English. Indeed, we found a slightly, but not statistically significant, positive influence for participants of group B (group A: $\bar{x}=1.84$; group B: $\bar{x}=2.17 ; t(34)=-0.57, p=0.572$ ).

We additionally claimed that there would be no differences between the groups in progressive (contrasting Imperfect and Preterite; $\mathrm{P}_{4}$ ), habitual ( $\mathrm{P}_{5}$ ) and continuous contexts (P6). All three predictions were confirmed as $t$-test results revealed no significant results for any of the contexts $\left(\mathrm{P}_{4}: t(34)=-.045, p=0.964\right.$; $\mathrm{P}_{5}: t(34)=-.189, p=.851$; 6 : $\left.t(34)=.270, p=.788\right)$. However, in habitual contexts both learner groups obtained rather high ratings (group A: $\bar{x}=1.76$; group $\mathrm{B}$ : 
$\bar{x}=1.92$ ), whereas in progressive and continuous contexts they struggled with contrasting the Imperfect and the Preterite.

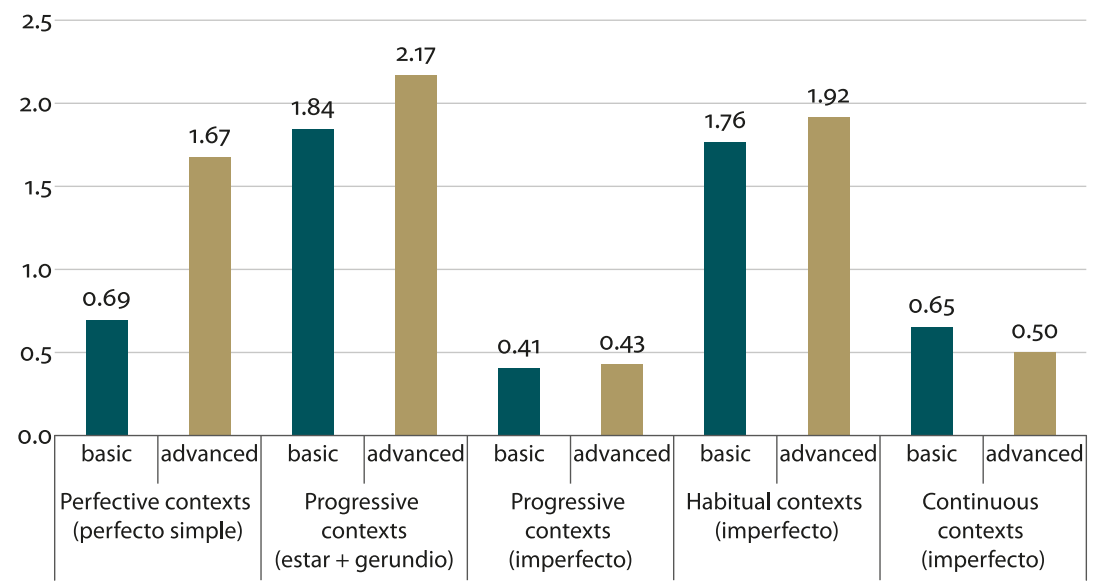

Figure 1. Results according to semantic contexts

These results led us to a more in-depth analysis of perfective contexts, where we examined whether the combination of grammatical and lexical aspect had any impact on transfer $\left(\mathrm{P}_{7}\right)$. We found a significant result for a prototypical combination of grammatical and lexical aspect (i.e., Preterite with telic predicates) $(t(34)=-2.32, p=0.027)$. Interestingly, the results were also similar for non-prototypical contexts (e.g., Preterite with stative predicates) $(t(34)=-2.04$, $p=.05)$. The only context for which the results were not significant was the combination of the Preterite with activity predicates $(t(34)=-1.06, p=0.299)$. However, there was a positive trend for all three combinations of the Preterite with all lexical aspectual classes (see Figure 2). Consequently, prediction 7 has to be rejected as the L2 had a positive effect in prototypical as well as in nonprototypical contexts.

\section{Discussion and concluding remarks}

It has been argued that $\mathrm{L}_{2}$ aspectual knowledge in English will positively influence the acquisition of perfective and imperfective aspect in $\mathrm{L}_{3}$ Spanish ( $\left.\mathrm{P}_{1}\right)$. However, positive effects have not been found on a global level, but only in specific semantic contexts (i.e., similarity relations; perfective/past $\left(\mathrm{P}_{2}\right)$ and progressive contexts with estar + gerundio $\left(\mathrm{P}_{3}\right)$ ). In contrast relations (i.e., progressive contexts with the Imperfect) we did not find any positive influence of aspectual knowledge in 


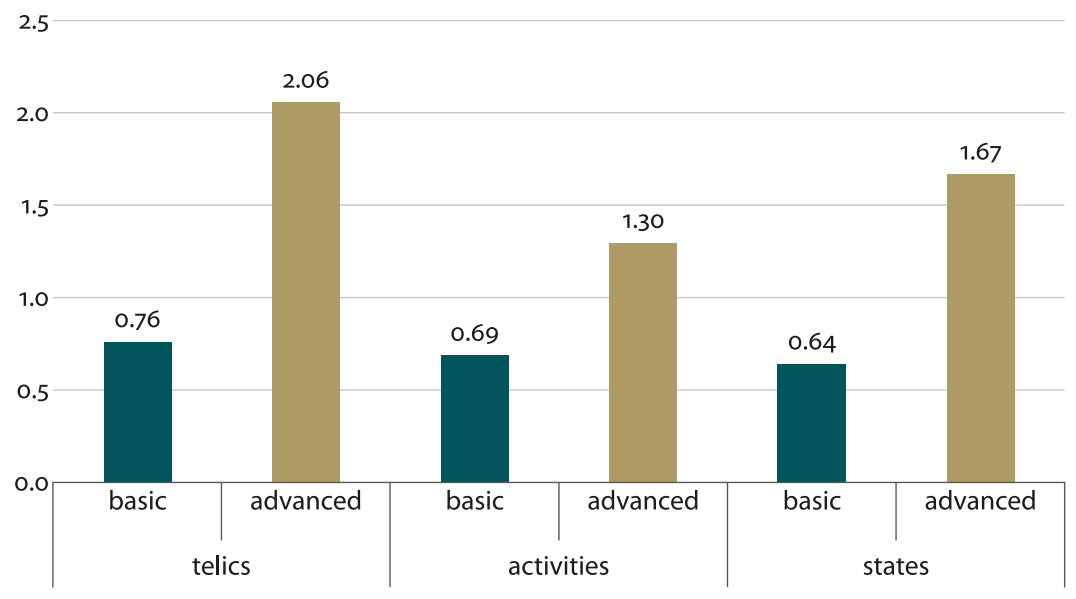

Figure 2. Results according to lexical aspect for perfective contexts

English ( $\left.\mathrm{P}_{4}\right)$. The same is true for contexts in which form-meaning-remapping is required (i.e., habitual and continuous contexts; $\mathrm{P}_{5}$ and $\mathrm{P} 6$ ). Finally, in perfective contexts, we found a positive influence of $\mathrm{L} 2$ aspectual knowledge in prototypical as well as in non-prototypical contexts $\left(\mathrm{P}_{7}\right)$.

In general, we argue that our findings are in line with the basic tenets of Salaberry's (2008) Default Past Tense Hypothesis. In contrast to Salaberry, however, we claim that, in our case, it is not the L1 system that is transferred, but the L2 (for a detailed argumentation, see Chapter 1 and 4). As Salaberry (2008, p. 213) argues, learners will transfer whatever inflectional or periphrastic markers of aspectual meaning they have in their L1 or, in our case, their L2. As German does not possess any inflectional or periphrastic markers to convey aspectual meaning, learners will rely on English, because it has a fully grammaticalized distinction between progressive and non-progressive aspect. This tendency is further strengthened by similar acquisition principles between the $\mathrm{L}_{2}$ and the $\mathrm{L}_{3}$ (Ullman, 2001) and learners' conscious desire to resort to their L2 as a learning strategy (De Angelis \& Selinker, 2001).

For past/perfective contexts, we argue that Spanish learners "simply equate Simple Past with Spanish Preterite" (Salaberry, 2008,p.215), which will mainly result in positive transfer of this semantic notion as both forms have "almost the same prototype" (Andersen, 2002, p. 89). Our results confirm this claim by showing that learners with advanced aspectual knowledge in English outperform learners who only have a basic understanding.

Regarding prediction 3, our results support the positive influence of the L2 only on a descriptive basis and no statistical generalisation can be drawn. However, if we look at the ratings of the participants, we can see that those ratings 
with estar + gerundio were high (between $\bar{x}=1.84$ and $\bar{x}=2.17$ ). These results indicate that learners, for this specific structure, might have already passed the initial developmental stage. Consequently, transfer from English to Spanish might have occurred at earlier stages of acquisition of this specific property. ${ }^{4}$ This claim is also confirmed by data of the language background questionnaire. Over $50 \%$ of learners said that they were able to transfer their rule knowledge from English to Spanish with regard to this specific feature (Eibensteiner \& Müller-Lancé, in preparation). Furthermore, in a stimulated-recall reflection task conducted after the participants had filled in the SITs, several participants compared the English and Spanish periphrases and said that English helped them to understand basic differences in Spanish as well. However, to empirically validate the claim of prediction 3, further research with less advanced learners is needed.

For progressive contexts contrasting the Imperfect and the Preterite $\left(\mathrm{P}_{4}\right)$, we argued that $\mathrm{L}_{2}$ aspectual knowledge will not positively influence the acquisition of Spanish. Due to the formal differences between the periphrastic be $+\mathrm{V}$-ing and the synthetic Imperfect, the learners are not able to realize the underlying semantic similarity (see Chapter 1 and 2). As a result, no boosting effect was found. Furthermore, as a consequence of the low ratings in this condition for both groups (between $\bar{x}=0.41$ and $\bar{x}=0.43$ ), we do not think that $\mathrm{L}_{3}$ learners "associate the aspectual value conveyed by the Imperfect in Spanish with the one conveyed by progressivity in English" (Salaberry, 2008,p.216), because this should have led to higher ratings in this condition and to an advantage of group B over group A. As argued above, we claim that learners do not map the English periphrasis onto the Imperfect but onto estar + gerundio. As learners usually think that one form can express only one meaning in initial developmental stages (Ringbom, 2007, p.55ff; see Section 1), they still have to learn that in Spanish progressivity can be expressed by two forms. As a consequence, they think that both forms provided in this condition (i.e., Preterite vs. Imperfect) are wrong and cannot be used to express progressive meaning in Spanish.

In habitual ( $\left.\mathrm{P}_{5}\right)$ and continuous contexts (P6) our results do not show any boosting effects either. However, these results might be related to the construction of the English SIT. As the task did not contain stative predicates or any items measuring the participants' knowledge of habitual aspect, we cannot exclude that the participants might have profited from their English knowledge, at least in habitual contexts. Some authors claim that English possesses a fully grammaticalized expression for habitual aspect expressed with the periphrasis used to

4. In fact, the German progressive periphrasis (i.e., Rheinische Verlaufsform) could have had some influence. However, as it is not very common and clearly not a grammatical device of standard German, it is rather unlikely that it influenced learners' decisions. 
+ infinitive or would + infinitive (e.g., Declerck, 2006). Consequently, learners might have mapped the English habitual periphrases onto the Spanish Imperfect, which could explain why the learners in both experimental groups obtained intermediate to high ratings (between $\bar{x}=1.76$ and $\bar{x}=1.92$ ).

Ringbom's (2007, p. 55f; see Section 1) claim that learners establish one-to-one cross-linguistic relationships between the target language and a unit in another language, in our case the L2, accounts exactly for our results. If we look at the three semantic contexts in which the learners obtained high ratings (i.e., perfective/past, habitual and progressive contexts with estar + gerundio; see Figure 1), these are exactly the contexts in which English uses inflectional or periphrastic markers to express those meanings. Consequently, as all the one-to-one mappings are established (see Table 2), the learners struggle with the distinction between the Preterite and the Imperfect in continuous and progressive contexts.

Table 2. Form-meaning-mappings between English and Spanish

\begin{tabular}{lll}
\hline English & Semantic context & Spanish \\
\hline Simple Past & past/perfective & Preterite \\
be + V-ing & progressive & estar + gerundio \\
used to / would + infinitive & habitual & Imperfect \\
\hline
\end{tabular}

Finally, our results show a positive effect of L2 English knowledge in prototypical as well as in non-prototypical combinations of lexical and grammatical aspect. This finding stands in contradiction to Salaberry's claim (Salaberry, in preparation) and empirical findings (Diaubalick et al., in preparation), which have shown that L2 knowledge positively influences an $\mathrm{L}_{3}$ only in prototypical contexts. How can we explain these contradictory findings? In Spanish, stative predicates can be used with the Preterite and the Imperfect. In English, however, states have to be used with the Simple Past as they cannot be combined with the progressive periphrasis. As a result, if the learners rely on their L2 English knowledge, they might assume that stativity is only combinable with the Preterite and not with the Imperfect. In fact, this would account for the positive effect found in non-prototypical perfective contexts (e.g., Preterite combined with states) as well as for the low ratings in continuous contexts (e.g., Imperfect combined with states). This finding is also a good argument against the influence of the L1 German, because in German stative predicates can be combined with both past tenses. L1 German transfer should, therefore, not cause any problems with combining states with the Imperfect.

In conclusion, we have argued that German-speaking learners of $\mathrm{L}_{3}$ Spanish activate their L2 English as a default transfer source and map the existing L2 items 
directly onto the $\mathrm{L}_{3}$ items, which leads to positive transfer in perfective/past, progressive (contrasting estar + gerundio with the Preterite) and habitual contexts.

Future studies, however, should assess habituality and stative predicates in more detail (e.g., integration of specific items into the L2 aspectual knowledge test). Additionally, different items looking at non-prototypical contexts as well as coercion contexts (e.g., Diaubalick \& Guijarro-Fuentes, 2019) should be investigated in more detail. Finally, the investigation of mirror image groups (i.e., L1 English/L2 German/L3 Spanish vs. L1 German/L2 English/L3 Spanish) or German-speaking L2 learners of Spanish with no English knowledge would also ameliorate our understanding of the $\mathrm{L}_{3}$ acquisition of Spanish.

\section{References}

Andersen, R. (2002). The dimension of "pastness". In R. Salaberry, \& Y. Shirai (Eds.), The L2 acquisition of tense-aspect morphology (pp. 79-105). Philadelphia: Benjamins. https://doi.org/10.1075/lald.27.06and

Andersson, S.-G. (2004). Gibt es Aspekt im Deutschen? In L. Gautier, \& D. Haberkorn (Eds.), Aspekt und Aktionsarten im heutigen Deutsch (pp. 1-11). Tübingen: Stauffenburg/Narr.

Bardel, C., \& Falk, Y. (2012). The L2 status factor and the declarative/procedural distinction. In J. Cabrelli Amaro, S. Flynn, \& J. Rothman (Eds.), Third language acquisition in adulthood (pp. 67-78). Amsterdam: John Benjamins. https://doi.org/10.1075/sibil.46.06bar

Bertinetto, P.M., \& Lenci, A. (2012). Habituality, plurifactionality, and imperfectivity. In R. Binnick (Ed.), The Oxford handbook of tense and aspect (pp. 852-880). New York: Oxford University Press.

Bertinetto, P. M., Ebert, K., \& De Groot, C. (2000). The progressive in Europe. In Ö. Dahl (Ed.), Tense and aspect in the languages of Europe (pp. 517-558). Berlin/New York: De Gruyter.

Comrie, B. (1976). Aspect. Cambridge: Cambridge University Press.

De Angelis, G., \& Selinker, L. (2001). Interlanguage transfer and competing systems in the multilingual mind. In J. Cenoz, B. Hufeisen, \& U. Jessner (Eds.), Cross-linguistic influence in third language acquisition (pp. 42-58). Clevedon/Buffalo/Toronto/Syndey: Multilingual Matters.

De Angelis, G. (2007). Third or additional language acquisition. Great Britain: Cromwell Press. Declerck, R. (2006). The grammar of the English verb phrase. Volume 1: The grammar of the English tense system. A comprehensive analysis. Berlin/New York: De Gruyter.

Diaubalick, T., \& Guijarro-Fuentes, P. (2019). The strength of L1 effects on tense and aspect: How German learners of L2 Spanish deal with acquisitional problems. Language Acquisition, 26(3), 282-301.

Diaubalick, T., Eibensteiner, L., \& Salaberry, R. (in preparation). Influence of L1/L2 linguistic knowledge on the acquisition of $\mathrm{L}_{3}$ Spanish past tense morphology among L1 German speakers. Manuscript submitted for publication. 
Domínguez, L., Tracy-Ventura, N., Arche, M., Mitchell, R., \& Myles, F. (2013). The role of dynamic contrasts in the L2 acquisition of Spanish past tense morphology. Bilingualism: Language and Cognition, 16(3), 558-577. https://doi.org/10.1017/S1366728912000363

Eibensteiner, L., \& Müller-Lancé, J. (in preparation). I am aprendiendo linguam hispanicam. Eine Untersuchung zum metasprachlichen Bewusstsein von Spanischlernenden. Manuscript submitted for publication.

Falk, Y., Lindqvist, Ch., \& Bardel, C. (2015). The role of L1 explicit metalinguistic knowledge in $\mathrm{L}_{3}$ oral production at the initial state. Bilingualism: Language and Cognition, 18(2), 227-235. https://doi.org/10.1017/S1366728913000552

Foote, R. (2009). Transfer in L3 acquisition: The role of typology. In Y. I. Leung (Ed.), Third language acquisition and universal grammar (pp. 89-114). Clevedon: Multilingual Matters.

Kellerman, E. (1983). Now you see it, now you don't. In S. Gass, \& L. Selinker (Eds.), Language transfer in language learning (pp. 112-134). Rowley: Newbury House.

Leisi, E., \& Mair, Ch. (2008). Das heutige Englisch: Wesenszüge und Probleme. Heidelberg: Winter.

Mair, Ch. (2012). Progressive and imperfective Aspect. In R. Binnick (Ed.), Tense and aspect (pp. 803-827). Oxford: Oxford University Press.

Montrul, S., \& Slabakova, R. (2002). The L2 acquisition of morphosyntactic and semantic properties of the aspectual tenses preterite and imperfect. In A.T. Pérez-Leroux, \& J. Muñoz Liceras (Eds.), The acquisition of Spanish morphosyntax (pp. 115-151).

Dordrecht: Kluwer. https://doi.org/10.1007/978-94-010-0291-2_5

Odlin, T. (1989). Language transfer: Cross-linguistic influence in language learning. Cambridge: Cambridge University Press. https://doi.org/10.1017/CBO9781139524537

Ringbom, H. (2007). Cross-linguistic similarity in foreign language learning. Clevedon/Buffalo/Toronto: Multilingual Matters.

Rothman, J. (2015). Linguistic and cognitive motivations for the Typological Primacy Model (TPM) of third language $\left(\mathrm{L}_{3}\right)$ transfer: Timing of acquisition and proficiency considered. Bilingualism: Language and Cognition, 18(2), 179-190. https://doi.org/10.1017/S136672891300059X

Salaberry, R. (2005). Evidence for transfer of knowledge of aspect from L2 Spanish to L3 Portuguese. In D. Ayoun, \& R. Salaberry (Eds.), Tense and aspect in Romance languages: Theoretical and applied perspectives (pp. 179-210). Philadelphia: John Benjamins. https://doi.org/10.1075/sibil.29.07sal

Salaberry, R. (2008). Marking past tense in second language acquisition. A theoretical model. London/New York: Continuum.

Salaberry, R. (2011). Assessing the effect of lexical aspect and grounding on the acquisition of L2 Spanish past tense morphology among L1 English speaker. Bilingualism: Language and Cognition, 14(2), 184-202. https://doi.org/10.1017/S1366728910000052

Salaberry, R. (in preparation). The conceptualization of knowledge about aspect. From monolingual to multilingual representations. Manuscript submitted for publication.

Tagliamonte, S., \& Lawrence, H. (2000). “I used to dance, but I don't dance now”. The habitual past in English. Journal of English Linguistics, 28(4), 324-353.

https://doi.org/10.1177/007542420002800402

Ullman, M. (2001). The neural basis of lexicon and grammar in first and second language: The declarative/procedural model. Bilingualism: Language and Cognition, 4(1), 105-122. https://doi.org/10.1017/S1366728901000220 
Yllera, A. (1999). Las perífrasis verbales de gerundio y participio. In V. Demonte, \& I. Bosque (Eds.), Gramática descriptiva de la lengua española. Vol. 2. Las construcciones sintácticas fundamentales. Relaciones temporales, aspectuales y modales (pp. 3391-3442). Madrid: Espasa Calpe.

Zagona, K. (2012). Tense and aspect. In J. I. Hualde, A. Olarrea, \& E. O’Rourke (Eds.), The handbook of hispanic linguistics (pp. 355-372). Oxford: Blackwell Publishing. https://doi.org/10.1002/9781118228098.ch18

\section{Address for correspondence}

Lukas Eibensteiner

Research Assistant

Department of Romance Languages

University of Mannheim

L15, 1-6

68131 Mannheim

Germany

eibensteiner@phil.uni-mannheim.de

https://orcid.org/oooo-00o3-0166-4477

\section{Publication history}

Date received: 7 January 2019

Date accepted: 2 December 2019 